\title{
OBSERVATIONS ON CARBON DIOXIDE TENSION DURING RECOVERY FROM METABOLIC ACIDOSIS ${ }^{1}$
}

\author{
By ROBERT W. WINTERS,2 JOHN A. LOWDER, ${ }^{3}$ AND NELSON K. ORDWAY 4 \\ (From the Departments of Pediatrics and Medicine, University of North Carolina School of \\ Medicine, Chapel Hill, N.C.)
}

(Submitted for publication December 3, 1957 ; accepted January 13, 1958)

The importance of hyperventilation in metabolic acidosis in minimizing the shift in blood $\mathrm{pH}$ is well known. It has been generally assumed that the stimulus for this augmented ventilation is the increased hydrogen ion concentration of the blood. If such were the case, it might be further assumed that during recovery from metabolic acidosis, the ventilation and hence the carbon dioxide tension would be adjusted in accordance with the $\mathrm{pH}$ of the blood.

This report presents data bearing upon the recovery of acid-base equilibrium in patients with metabolic acidosis due to diabetes, to diarrheal disease and to renal disease. The results show the frequent occurrence of normal or even alkaline blood $\mathrm{pH}$ values associated with reduced $\mathrm{pCO}_{2}$ values during the recovery phase, and imply that some degree of hyperventilation persists in the absence of a measurable chemical stimulus in the blood.

\section{METHODS}

The data presented include measurements of whole blood $\mathrm{pH}$, plasma carbon dioxide content, and calculated plasma carbon dioxide tension $\left(\mathrm{pCO}_{2}\right)$ in 10 children and 1 adult with diabetic acidosis, in 27 infants and children with diarrheal acidosis, and in 3 children and 5 adults with uremic acidosis who were studied on the wards of the North Carolina Memorial Hospital, Chapel Hill, and the L.S.U. division of Charity Hospital, New Orleans. In nearly every instance, heparinized venous blood drawn without stasis was used; the remaining few determinations were performed on arterial blood.

Whole blood $\mathrm{pH}$ was determined by the glass electrode, either at $37^{\circ} \mathrm{C}$., or at room temperature and corrected

\footnotetext{
1 Presented at the Eleventh Annual Meeting of the Southern Society for Clinical Research, New Orleans, January 26, 1957.

2 Postdoctoral Fellow, National Foundation for Infantile Paralysis.

3 Present address: Department of Medicine, University of Alabama School of Medicine, Birmingham, Ala.

4 Present address: Department of Pediatrics, Yale University School of Medicine, New Haven, Conn.
}

to $37^{\circ}$ C. using Rosenthal's (1) temperature coefficient. Total carbon dioxide content was determined by the method of Van Slyke and Neill (2). Plasma carbon dioxide tension $\left(\mathrm{pCO}_{2}\right)$ was calculated according to the Henderson-Hasselbalch equation, using a value of 6.11 for $\mathrm{pK}^{\prime}$ and a $\mathrm{CO}_{2}$ solubility factor of 0.0311 (3).

\section{Diabetic acidosis}

Figure 1 shows the acid-base data for the diabetic patients, together with similar data from various sources in the literature (4-11). In this and in subsequent figures, the total carbon dioxide content of the plasma is plotted logarithmically on the ordinate, while whole blood $\mathrm{pH}$ is plotted on the abscissa. On such a plot, the loci for various values of carbon dioxide tension for arterial blood at $37^{\circ} \mathrm{C}$. are defined by the nearly straight lines which transect the major axes. Two points are plotted for each patient, the first representing the data obtained prior to treatment, and the second representing the earliest observation of a normal or alkaline $\mathrm{pH}$ after institution of treatment. The latter point was obtained in two hours to four days; in 39 of 51 patients this observation was within 24 hours.

Prior to treatment, all patients were in metabolic acidosis, the average $\mathrm{pH}$ for the entire group being 7.08 , and the average total carbon dioxide content being $7.4 \mathrm{mM}$ per L. All patients received insulin and parenteral fluids, and in some instances (literature cases only), large amounts of either sodium bicarbonate or sodium lactate.

The post-treatment data show that most of the patients attained blood $\mathrm{pH}$ values of 7.35 or greater, while the $\mathrm{pCO}_{2}$ was still low. This is unequivocally the case in 39 of the 51 patients. These findings are especially significant in view of the fact that over two-thirds of the data of Figure 1 was obtained from venous blood; had arterial data been available, the $\mathrm{pCO}_{2}$ values would 


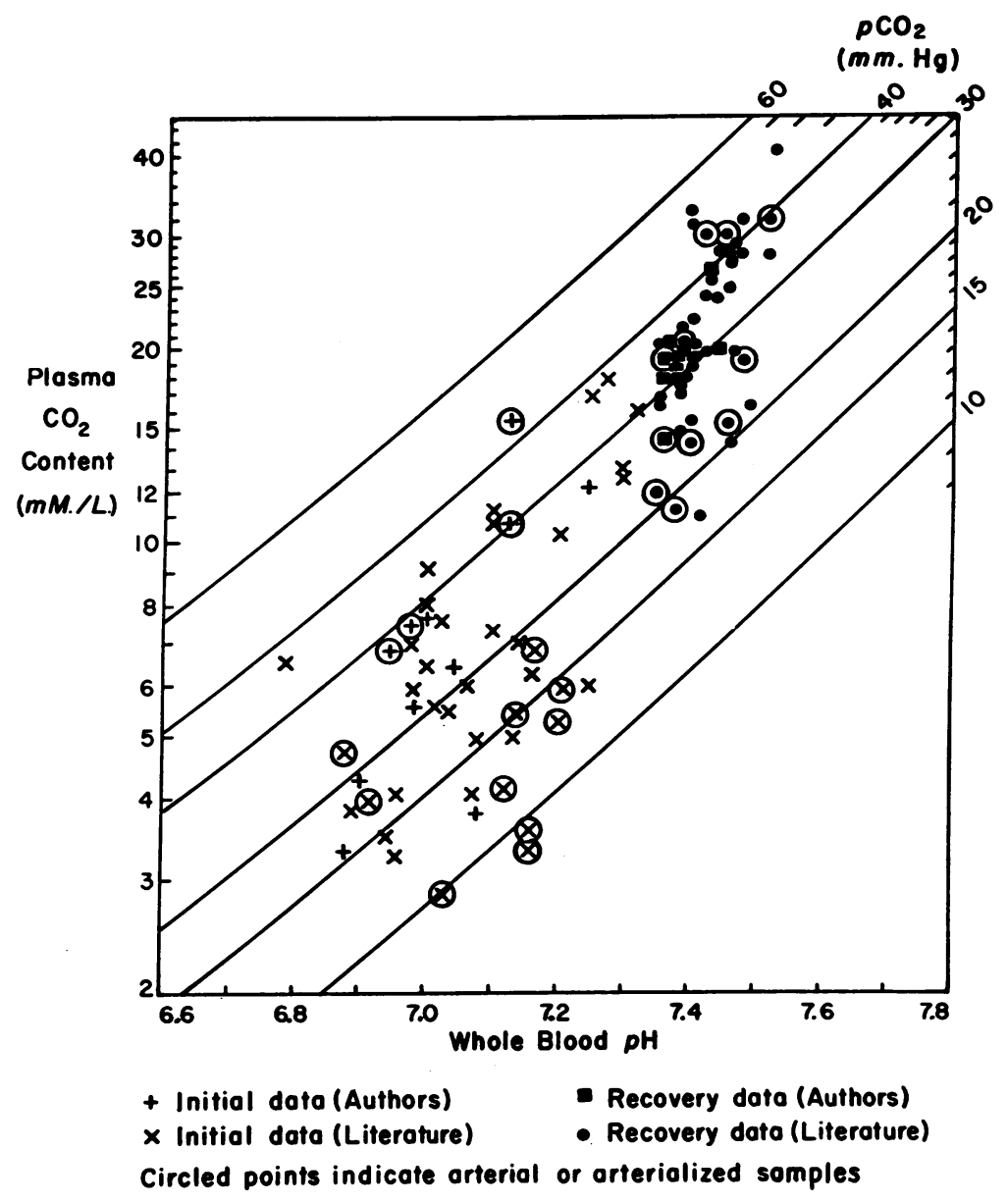

Fig. 1. Diabetic Acibosis

have been even lower than those shown in the figure.

\section{Diarrheal acidosis}

Data similar to those of the diabetic patients are shown in Figure 2 for 27 infants and children with diarrhea, along with similar data from the literature (12). The initial data show that all patients were in a state of metabolic acidosis (average $\mathrm{pH}, 7.22$; average $\mathrm{CO}_{2}$ content, 13.3 $\mathrm{mM}$ per L.). Although the post-treatment point on each patient was, in general, reached at a longer interval after the first than in the diabetic subjects (24 of the 42 within 2 days; range, 6 hours to 17 days), the same phenomenon is apparent in these cases also in that 30 of the 42 patients achieved a normal or supernormal $\mathrm{pH}$ associated with a $\mathrm{pCO}_{2}$ of less than $40 \mathrm{~mm}$. $\mathrm{Hg}$. Here, too, the use of acid-base data from venous blood masks the even greater depression of $\mathrm{pCO}_{2}$ present in the arterial blood of the patients.

\section{Uremic acidosis}

In Figure 3 are shown data derived from a study of eight uremic patients before and from 14 hours to 4 days after therapy consisting of rehydration, which in most instances included sodium bicarbonate infusions. Also shown are data of Yeomans and Stueck (13) on four patients managed in a simliar manner, as well as data from the report of Weller, Swan, and Merrill (14) on uremic patients before and from four to six hours after extracorporeal dialysis. As in the case of the patients with diabetic and diarrheal acidosis, most of the patients with uremic acidosis attained a 


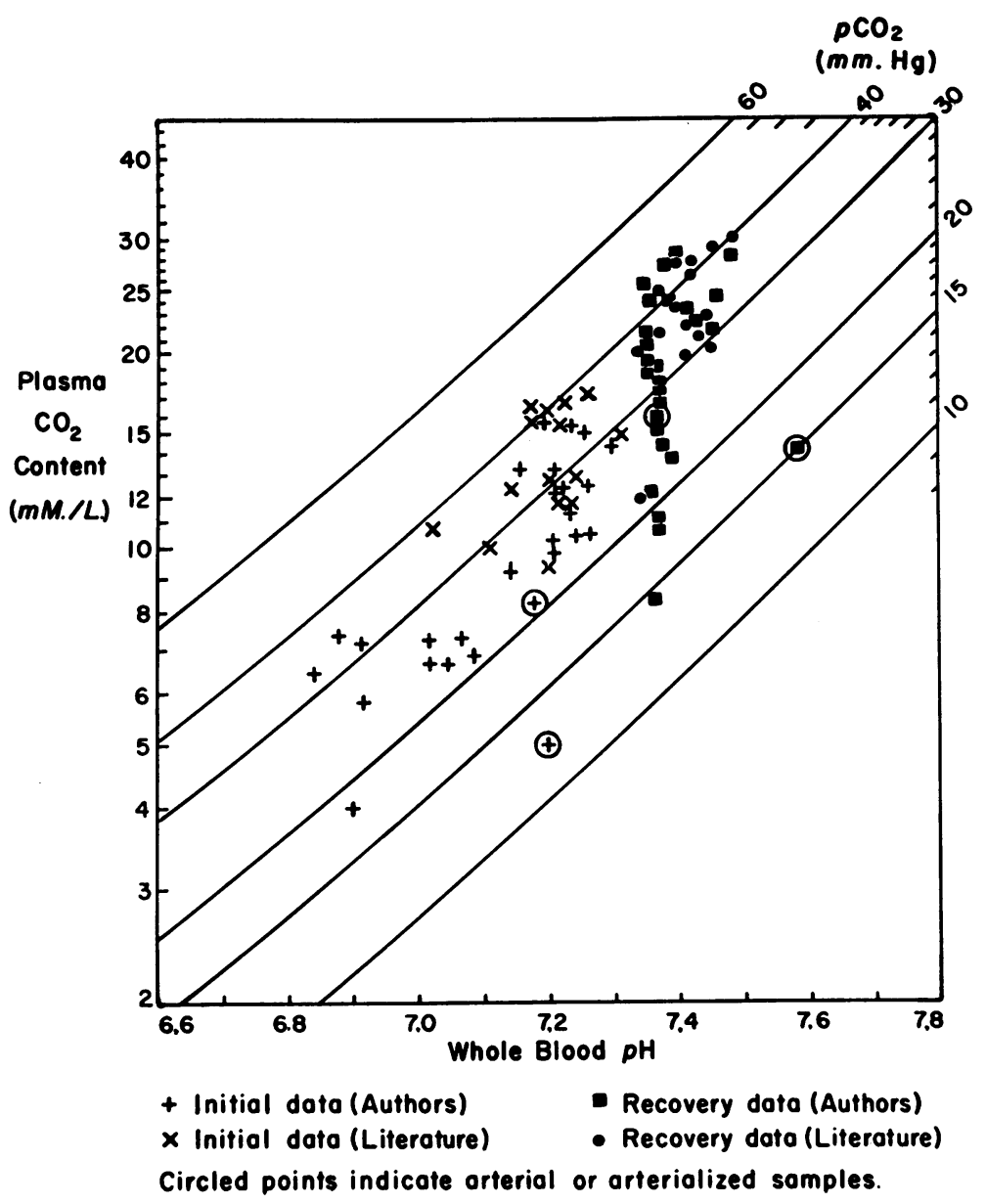

Fig. 2. Diarrheal Acidosis

normal or alkaline $\mathrm{pH}$ associated with distinctly depressed values for $\mathrm{pCO}_{2}$.

\section{DISCUSSION}

The data presented clearly show that a majority of the patients recovering from diabetic acidosis pass through a point at which the $\mathrm{pH}$ is normal or elevated but the $\mathrm{pCO}_{2}$ is depressed. This observation, apparently first made by Peters (15) in 1917 , has been repeatedly confirmed $(4-11,16)$ in diabetic patients.

Delayed return of $\mathrm{pCO}_{2}$ to normal appears to be a feature not unique to diabetic acidosis, since a similar phenomenon was observed in patients recovering from diarrheal acidosis and uremic acidosis. Furthermore, published observations by others $(17,18)$ on subjects recovering from am- monium chloride acidosis show a similar pattern (see Figure 3).

The findings of $\mathrm{pCO}_{2}$ values lower than normal suggest that hyperventilation is in some measure sustained, a contention supported by ventilation measurements reported by Kety, Polis, Nadler, and Schmidt (8). The mechanisms underlying the continued hyperventilation by such patients are not clear. It is apparent that within the confines of Gray's multiple factor theory for the chemical control of pulmonary ventilation (19) there is no discernible stimulus in the arterial blood for the augmented ventilation, since $\mathrm{pCO}_{2}$ is reduced, hydrogen ion is either normal or reduced, and $\mathrm{pO}_{2}$ is presumably elevated due to the hyperventilation.

One explanation might be that the sensitivity of the respiratory center to $\mathrm{pCO}_{2}$ and/or hydrogen 


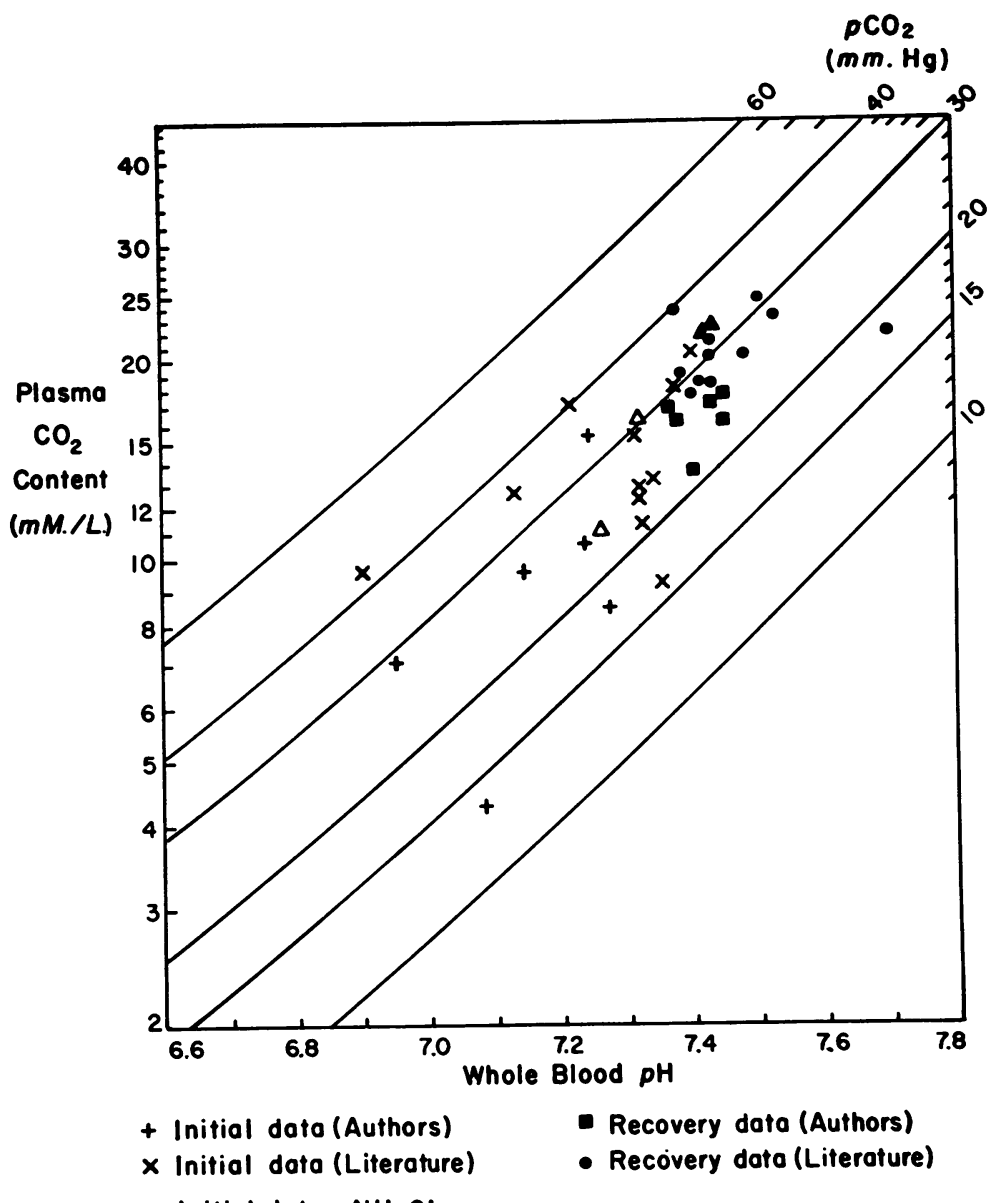

$\Delta$ Initial data $-\mathrm{NH}_{4} \mathrm{Cl}$

$\triangle$ Recovery data $-\mathrm{NH}_{4} \mathrm{Cl}$

All data ore arterial.

Fig. 3. Uremic and $\mathrm{NH}_{4} \mathrm{Cl}$ Acidosis

ion has been increased. Increased sensitivity, assessed by a change in the slope of the curve relating the alveolar ventilation ratio to arterial $\mathrm{pCO}_{2}$ during inhalation of various concentrations of carbon dioxide, has indeed been demonstrated in other situations in which there has been susstained hypocapnia but with alkalosis; viz., passive hyperventilation of normal subjects (20) and acclimatization to high altitude (21). The opposite response, decreased sensitivity to $\mathrm{pCO}_{2}$, has been adequately demonstrated in chronic hypercapnic states (22-25).

Direct studies dealing with the sensitivity to $\mathrm{pCO}_{2}$ of subjects with metabolic acidosis have been reported in only a few instances. Tenney (22) showed a clearcut increase in one patient with a chronic ammonium chloride acidosis and a reversion to normal after full recovery from the acidosis. Alexander, West, Wood, and Richards (23) found increased sensitivity in one of three patients with mild degree of metabolic acidosis secondary to chronic renal disease, while Nielson (26) detected only slight or no change with acute ammonium chloride acidosis. These conflicting results obtained by different investigators may be due to the different intensities and different durations of the acidosis present in the subjects and are not necesarily incompatible with the explanation offered for the findings reported above.

The mechanisms mediating increased sensitivity of the respiratory center are not understood. A reduction in the buffer capacity of the blood is hardly a single satisfactory explanation, since this would not explain the development of the frankly alkalotic $\mathrm{pH}$ values which were observed in some of the patients. 
It is likely that the mechanism of increased sensitivity involves alteration of local chemical conditions, i.e., in the cells of the respiratory center or in the cerebrospinal fluid. In this connection, it is pertinent to note that recent experiments by Leusen (27) and by Winterstein and Gökhan (28) have shown that the $\mathrm{pH}$ of the spinal fluid varies directly with that of the blood in acute respiratory disturbances of acid-base equilibrium, but inversely with that of the blood in acute metabolic disturbances. These findings imply that carbon dioxide freely permeates into spinal fluid but that bicarbonate does not. In more prolonged experiments (up to 48 hours) in cats with ammonium chloride acidosis, the carbon dioxide combining power of the spinal fluid did fall, but the degree was not quantitatively comparable with that observed in the blood (29). A lag in recovery of bicarbonate in spinal fluid of the order suggested by these studies might provide a mechanism for the change in sensitivity.

With respect to changes within the buffer content of the cells themselves, Brown found a reduced buffering capacity of the homogenates of brains of guinea pigs who had hyperventilated secondary to hypoxia (30). The magnitude of the change was such as to suggest that a real change in the buffer content of the intracellular fluids had occurred and the results obtained were not explicable solely by a change in the extracellular phase of the tissue.

In terms of the concept of alteration of local chemical environment, the findings observed in subjects recovering from metabolic acidosis could be explained if there was a significant lag in the recovery of the buffer capacity of the cerebrospinal fluid or the cells themselves, whereby respiration and hence carbon dioxide tension were controlled primarily by local conditions rather than by the $\mathrm{pH}$ and $\mathrm{pCO}_{2}$ of the arterial blood.

\section{SUM MARY}

1. Patients recovering from diabetic, diarrheal or uremic acidosis frequently pass through a phase at which blood $\mathrm{pH}$ is normal or supernormal but at which $\mathrm{pCO}_{2}$ is still depressed. This suggests that there is sustained hyperventilation on the part of such patients even though they are no longer acidotic.
2. It is suggested that such patients may have an increased sensitivity of the respiratory center to $\mathrm{pCO}_{2}$ and/or hydrogen ion to account for the continuing hyperventilation.

\section{REFERENCES}

1. Rosenthal, T. B. The effect of temperature on the $\mathrm{pH}$ of blood and plasma in vitro. J. biol. Chem. 1948, 173, 25.

2. Van Slyke, D. D., and Neill, J. M. The determination of gases in blood and other solutions by vacuum extraction and manometric measurement. I. J. biol. Chem. 1924, 61, 523.

3. Singer, R. B., and Hastings, A. B. An improved clinical method for the estimation of disturbances of the acid-base balance of human blood. Medicine 1948, 27, 223.

4. Cullen, G. E., and Jonas, L. The effect of insulin treatment on the hydrogen ion concentration and alkalai reserve of the blood in diabetic acidosis. J. biol. Chem. 1923, 57, 541.

5. Hartmann, A. F., and Darrow, D. C. Chemical changes occurring in the body as the result of certain diseases. III. The composition of the plasma in severe diabetic acidosis and the changes taking place during recovery. J. clin. Invest. 1928, $6,257$.

6. Hartmann, A. F., and Erganian, J. Treatment of diabetic acidosis. J. Pediat. 1947, 31, 274.

7. Guest, G. M., and Rapoport, S. Electrolytes of blood plasma and cells in diabetic acidosis and during recovery. Proc. Amer. Diabetes Ass. 1947, 7, 95.

8. Kety, S. S., Polis, B. D., Nadler, C. S., and Schmidt, C. F. The blood flow and oxygen consumption of the human brain in diabetic acidosis and coma. J. clin. Invest. 1948, 27, 500.

9. Nichols, G., Jr., and Nichols, N. Electrolyte equilibria in erythrocytes during diabetic acidosis. J. clin. Invest. 1953, 32, 113.

10. Talbot, N. B., Kerrigan, G. A., Crawford, J. D., Cochran, W., and Terry, M. Application of homeostatic principles to the practice of parenteral fluid therapy (concluded). New Engl. J. Med. 1955, 252, 898.

11. Bock, A. V., Field, H., Jr., and Adair, G. S. The acid-base equilibrium in diabetic coma being a study of five cases treated with insulin. J. metab. Res. 1923, 4, 27.

12. Cheek, D. B. Changes in total chloride and acidbase balance in gastroenteritis following treatment with large and small loads of sodium chloride. Pediatrics 1956, 17, 839.

13. Yeomans, A., and Stueck, G. H., Jr. Clinical-chemical studies of acid-base abnormalities. Changes in acid-base balance observed in renal and respiratory disease. Amer. J. Med. 1952, 13, 183. 
14. Weller, J. M., Swan, R. C., and Merrill, J. P. Changes in acid-base balance of uremic patients during hemodialysis. J. clin. Invest. 1953, 32, 729.

15. Peters, J. P., Jr. The response of the respiratory mechanism to rapid changes in the reaction of the blood. Amer. J. Physiol. 1917, 44, 84.

16. Stillman, E., Van Slyke, D. D., Cullen, G. E., and Fitz, R. Studies of acidosis. VI. The blood, urine and alveolar air in diabetic acidosis. J. biol. Chem. 1917, 30, 405.

17. Sartorius, O. W., Roemmelt, J. C., and Pitts, R. F. The renal regulation of acid-base balance in man. IV. The nature of the renal compensations in ammonium chloride acidosis. J. clin. Invest. 1949, 28, 423.

18. Dennig, H., Dill, D. B., and Talbott, J. H. Bilanzuntersuchung einer Salmiakazidose. NaunynSchmiedeberg's Arch. exp. Path. Pharmak. 1929, 144, 297.

19. Gray, J. S. Pulmonary ventilation and its physiological regulation in American Lecture Series, Publication No. 63. Springfield, Charles C Thomas, 1950.

20. Brown, E. B., Jr., Hemmingway, A., and Visscher, M. B. Arterial blood $\mathrm{pH}$ and $\mathrm{pCO}_{2}$ changes in response to $\mathrm{CO}_{2}$ inhalation after 24 hours of passive hyperventilation. J. appl. Physiol. 1950 2, 544.

21. Rahn, H., Stroud, R. C., Tenney, S. M., and Mithoefer, J. C. Adaptation to high altitude: Respiratory response to $\mathrm{CO}_{2}$ and $\mathrm{O}_{2}$. J. appl. Physiol. 1953, 6, 158.

22. Tenney, S. M. Ventilatory response to carbon diox- ide in pulmonary emphysema. J. appl. Physiol. 1954, 6, 477.

23. Alexander, J. K., West, J. R., Wood, J. A., and Richards, D. W. Analysis of the respiratory response to carbon dioxide inhalation in varying clinical states of hypercapnia, anoxia, and acidbase derangement. J. clin. Invest. 1955, 34, 511.

24. Schäfer, K. E. Atmung und Säure-Basengleichgewicht bei langdaurerndem Aufenthalt in $3 \% \mathrm{CO}_{2}$. Pflüg. Arch. ges. Physiol. 1949, 251, 689.

25. Chapin, J. L., Otis, A. B., and Rahn, H. Changes in sensitivity of respiratory center in man after prolonged exposure to $3 \% \quad \mathrm{CO}_{2}$. Wright Air Development Center Technical Report 55-357, No. 27, Nov., 1955.

26. Nielsen, M. Untersuchungen über die Atemregulation beim Menschen, besonders mit Hinblick auf die Art des chemischen Reizes. Skand. Arch. Physiol. 1936, Suppl. 10, 87.

27. Leusen, I. R. Acid-base equilibrium between blood and cerebrospinal fluid. Amer. J. Physiol. 1954, 176,513

28. Winterstein, H., and Gökhan, N. Ammoniumchlorid-Acidose und Reaktionstheorie der Atmungsregulation. Arch. int. Pharmacodyn. 1953, 93, 212.

29. de Thurzo, E., and Katzenelbogen, S. Alkalai reserve in blood and in cerebrospinal fluid in experimental acidosis. Arch. Neurol. Psychiat. 1935, 33, 786.

30. Brown, E. B., Jr. Changes in brain $\mathrm{pH}$ response to $\mathrm{CO}_{2}$ after prolonged hypoxic hyperventilation. J. appl. Physiol. 1950, 2, 549. 